Our Nature (2005)3:26-30

\title{
Preliminary Report of Diatoms from Maipokhari Lake, Ilam, Nepal
}

\author{
S.K. Rai \\ Department of Botany, P.G. Campus, Tribhuvan University, Biratnagar, Nepal \\ Email: shivarai2003@yahoo.com
}

\begin{abstract}
The present paper deals with 10 taxa belonging to 5 genera of Bacillariophycean algae first time from Maipokhari Lake of Ilam district. Out of these, 8 taxa viz., Eunotia diodon Ehr., E. gracilis (Ehr.) Rabenh., E. monodon Ehr. var. bidens (Greg.) Sm., E. monodon Ehr. var. tropica Hust., Navicula placenta Ehr., Pinnularia conica Gandhi, P. sundaensis Hust. and Hantzschia amphioxys (Ehr.) Grun. var. capitata Muell. are being reported for the first time from Nepal.
\end{abstract}

Key words: Algae, Bacillariophyceae, Diatom, Ilam, Maipokhari Lake, Nepal

\section{Introduction}

Diatom of Nepal has not been studied so far properly except some scanty works mainly from high altitude regions. Thus, very little information is available regarding their taxonomy and diversity in the country. A perusal of literature shows that the first record of diatom from Nepal was Navicula confervacea reported by Carter (1926) from Makawanpur district. A major contribution in the Nepalese diatom flora was made by Hirano $(1955,1963,1984)$ who has described more than 176 taxa from high altitude Himalayan region of eastern and central Nepal. Later on, Suxena and Venkateswarlu (1968), Suxena et al. (1972), Hickel (1973, 1973a), Shrestha and Manandhar (1983), Ishida (1986), Aryal and Lacoul (1996), Habib (1997) and Rothfritz et al. (1997) have reported many diatoms from different parts of the country.

Maipokhari is a natural and religious lake situated at an elevation of $2,150 \mathrm{~m}$ just about $12.8 \mathrm{~km}$ north-west from Ilam Bazar. It has about 1 mile circumference with 9 distinct corners. There is no any report on diatom of
Maipokhari Lake till the date. Hence, a preliminary attempt has been made to present an account of the same.

Materials and Methods

Algal samples were collected by squeezing aquatic macrophytes and using a plankton net (mesh size $0.5 \mathrm{~mm}$ ) from different corners of the lake between $09.00 \mathrm{~h}$ and $11.00 \mathrm{~h}$ during the rainy season of 2004. Samples were preserved in 3-4\% unbuffered formalin and frustules were cleaned following Patrick and Reimer (1966). Identification of species was by use of a Laica binocular microscope and relevant monographs. All the drawings were made from the permanent slides prepared in canada balsam with the help of cameralucida. The classification of taxa here is according to Hendy (1964). Abbreviations and symbols used in the text are as $\mathrm{CN}=$ Collection number, $\mathrm{DC}=$ Date of collection, $\mathrm{DN}=$ Distribution in Nepal and $\left({ }^{*}\right)$ Asterisk= New to Nepal.

\section{Taxonomic Description}

Order: Bacillariales 
Sub-order: Eunotiineae

Family: Eunotiaceae

Genus: Eunotia Ehrenberg 1837

1. *Eunotia diodon Ehr. (Fig. 1)

Foged, N. 1982, P. 351, Pl. 1, Fig. 18; Pl. 5, Fig. 20.

Valves $30.5 \mu \mathrm{m}$ long, $7.5 \mu \mathrm{m}$ broad, arcuate, dorsal margin convex with two uniform hemps, ventral margin concave; ends broadly rounded, somewhat narrowed on the dorsal side; raphe small; polar nodules distinct at the apices near ventral margin; striae 15 in $10 \mu \mathrm{m}$, fine, lineate.

CN 276, DC 19-06-2004.

2. *Eunotia gracilis (Ehr.) Rabenh. (Fig. 4) Hustedt, F. 1959, P. 305, Fig. 771; Foged, N. 1986, P. 561, Pl. 2, Fig. 1.

Valves $117 \mu \mathrm{m}$ long, $5.5 \mu \mathrm{m}$ broad, slender, more or less straight, slightly arched at the middle, almost parallel margins; ends swollen, rounded; polar nodules small, on the ventral margin near the apices; striae 12-13 in $10 \mu \mathrm{m}$, fine, lineate, parallel.

CN 280, DC 20-06-2004.

3. *Eunotia monodon Ehr. var. bidens (Greg.) Sm. (Fig. 2)

Hustedt, F. 1959, P. 305, Fig. 772d; Foged, N. 1982, P. 351, Pl. 5, Fig. 13.

Valves $67.5 \mu \mathrm{m}$ long, $12.5 \mu \mathrm{m}$ broad, slightly arched, dorsal margin convex with two wavy ridges at the middle, gradually narrowing towards the ends, ventral margin concave; ends slightly constricted on the dorsal side, slightly produced, rounded; raphe thin; polar nodules distict, on the ventral side near the apices; striae 12 in $10 \mu \mathrm{m}$, coarse, lineate, parallel, some what radiate and closely placed near apices.

CN 270, DC 19-06-2004.
4. *Eunotia monodon Ehr. var. tropica Hust.

(Fig. 3)

Hustedt, F. 1938, P. 171, Pl. 11, Figs. 3-6.

Valves $95 \mu \mathrm{m}$ long, $14 \mu \mathrm{m}$ broad, slightly arched, dorsal margin convex with four wavy ridges, ventral margin slightly concave, lineate; ends broadly rounded; raphe thin; polar nodules distinct, on the ventral side near the apices; striae 12 in $10 \mu \mathrm{m}$, coarse, lineate, parallel in the middle but somewhat radiate and closely placed near apices.

CN 275, DC 19-06-2004.

Sub-order: Naviculineae

Family: Naviculaceae

Genus: Navicula Bory 1822, Cleve 1894

5. *Navicula placenta Ehr. (Figs. 5-6)

Hustedt, F. 1938, P. 257, Pl. 20, Fig. 30; 1961-66, P. 342, Fig. 1452b.

Valves $35 \mu \mathrm{m}$ long, $15 \mu \mathrm{m}$ broad, broadly elliptical with convex margins; ends slightly produced, slightly capitate rounded; raphe thin, straight; central nodules distinct; axial area narrow, linear; central area somewhat obliquely rectangular; striae 22 in $10 \mu \mathrm{m}$, very fine.

CN 278, DC 20-06-2004.

Genus: Pinnularia Ehrenberg 1840

\section{6. *Pinnularia borealis Ehr. (Fig. 9)}

Hustedt, F. 1938, P. 393, Pl. 21, Fig. 7; Foged, N. 1986, P. 567, Pl. 5, Fig. 20.

Valves $52.5 \mu \mathrm{m}$ long, $12 \mu \mathrm{m}$ broad, linear, more or less parallel margins with slightly tapering, broadly rounded ends; raphe thick, straight, placed on one side with distinct, unilaterally curved central nodules and curved terminal fissures; axial area distinct, linear; central area large reaching the sides; striae 6 in $10 \mu \mathrm{m}$, coarse, 2-3 middle striae short and thick, radiate in the middle, convergent towards apices. 
CN 275, DC 19-06-2004.

DN: A stream at Wolangchung Gola, Taplejung (Hirano, 1984).

\section{7. *Pinnularia conica Gandhi (Fig. 8)} Gandhi, H. P. 1956-57, P. 847, Figs. 9-10; 1960, P. 111, Pl. 2, Figs. 57-58.

Valves $63 \mu \mathrm{m}$ long, $10.5 \mu \mathrm{m}$ broad, linearlanceolate, very slightly convex to rarely subparallel sides with slightly but distinctly constricted, produced, slightly capitate-cuneate ends; raphe thin, straight with distinct central nodules and curved terminal fissures; axial area narrow, linear; central area large, reaching the sides; striae 10-11 in $10 \mu \mathrm{m}$, coarse, strongly radial in the middle, convergent towards apices. CN 277, DC 20-06-2004.

\section{8. *Pinnularia sundaensis Hust. (Fig. 7)} Hustedt, F. 1938, P. 402, Pl. 23, Figs. 1-2.

Valves $185.5 \mu \mathrm{m}$ long, $25 \mu \mathrm{m}$ broad, large, linear, inflation slightly in the middle and very slightly towards poles with broadly rounded ends; raphe thick, median, undulate with unilaterally bent central nodules and distinctly curved terminal fissures; axial area broad, linear, about $1 / 3$ of the breadth of valve; central area rounded; striae 7-8 in $10 \mu \mathrm{m}$, coarse, lineate, slightly radiate in the middle, convergent towards apices.

CN 276, DC 19-06-2004.

Family: Cymbellaceae

Genus: Cymbella C.A. Agardh 1830

9. *Cymbella cistula (Hempr.) Kirchn. (Fig. 10) Tiffany, L.H. and M.E. Britton 1952, P. 278, Pl. 74, Fig. 861; Foged, N. 1982, P. 355, Pl. 8, Fig. 13.

Valves $119 \mu \mathrm{m}$ long, $23 \mu \mathrm{m}$ broad, ventricose, curved, asymmetric, dorsal side convex, ventral side slightly concave with middle inflation; ends slightly constricted, produced area. rounded; raphe thick, arcuate, excentric with ventrally curved central nodules; axial area not narrow; central area elliptical with 3-4 isolated stigmata at the ends of the middle ventral striae; striae 7-10 in $10 \mu \mathrm{m}$, punctate, radiate.

CN 277, DC 20-06-2004.

DN: Dudh Koshi river on the way from Dudh Pokhari to Dole village, Solukhumbu, $4790 \mathrm{~m}$ (Suxena and Venkateswarlu, 1968); a stream at Kungbachen, 4150 m (Hirano, 1984).

Family: Bacillariaceae

Genus: Hantzschia Grunow 1880

10. *Hantzschia amphioxys (Ehr.) Grun. var. capitata Muell. (Fig. 11)

Tiffany, L.H. and M.E. Britton 1952, P. 289, Pl. 75, Fig. 887; Florin, M.B. 1970, P. 683, Pl. 8, Fig. i.

Valves $67.5 \mu \mathrm{m}$ long, 7-8 $\mu \mathrm{m}$ broad, linear, dorsal side convex, ventral side slightly concave with distinct depression in the middle; ends slightly attenuated, constricted rounded to capitate; keel punctae 7-8 in $10 \mu \mathrm{m}$, coarse, distinct, thick, slightly elongated, median to distantly placed; striae fine, lineate, parallel.

CN 274, DC 19-06-2004.

\section{Results and Discussion}

During the present investigation, a total of 10 taxa belonging to 5 genera of class Bacillariophyceae have been reported on the basis of morphotaxonomic observation. Out of these, 8 taxa viz. Eunotia diodon, E. gracilis, E. monodon var. bidens, E. monodon var. tropica, Navicula placenta, Pinnularia conica, P. sundaensis and Hantzschia amphioxys var. capitata are the new records for the country. So far, no work has been done on the algal flora of Ilam, hence all these forms constitute new records from the 
S. K. Rai / Our Nature (2005)3:26-30

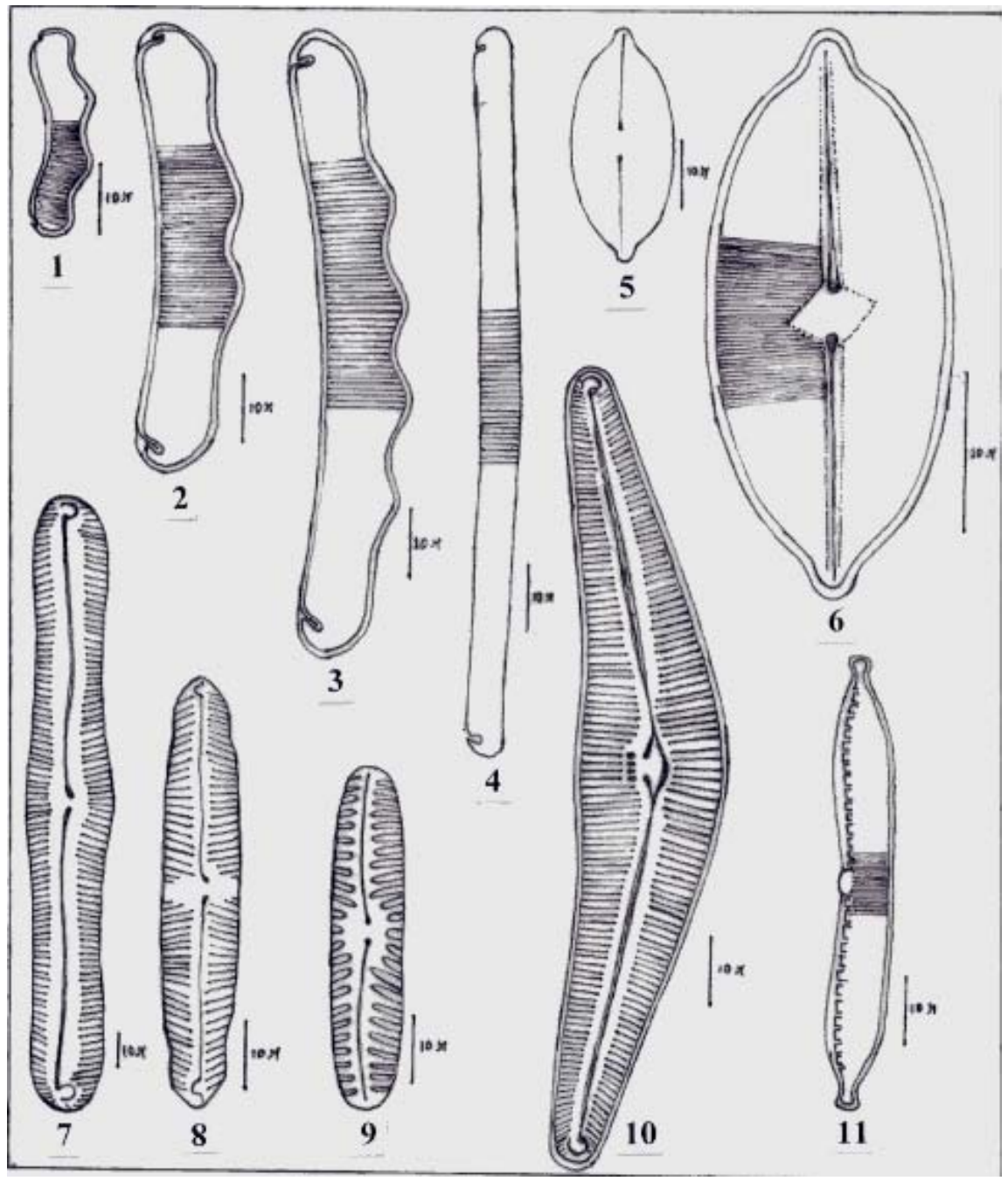

Figures: 1. Eunotia diodon Ehr. 2. Eunotia monodon Ehr. var. bidens (Greg.) Sm. 3. Eunotia monodon Ehr. var. tropica Hust. 4. Eunotia gracilis (Ehr.) Rabenh. 5-6. Navicula placenta Ehr. 7. Pinnularia sundaensis Hust. 8. Pinnularia conica Gandhi 9. Pinnularia borealis Ehr. 10. Cymbella cistula (Hempr.) Kirchn. 11. Hantzschia amphioxys (Ehr.) Grun. var. capitata Muell. 
Due to natural and unpolluted lentic water, the lake harbour rich assemblage of various algal forms. Genus Eunotia is found to be dominant with its diverse forms.

\section{Acknowledgements}

I am grateful to Dr. P.K. Misra, Department of Botany, University of Lucknow, India for the help in identification of diatoms. I also thank the Director, NBRI, Lucknow for library facilities. Thanks are due to UGC, Nepal for the financial assistance.

\section{References}

Aryal, S. and P. Lacoul 1996. Water quality and diversity of diatoms in Punyamati river, Nepal. Ecoprint 3(1): 45-49.

Carter, N. 1926. Fresh water algae from India. Records bot. Surv. India 9(4): 263-302.

Florin, M.B. 1970. Late-glacial diatoms of Kirchner Marsh, South Eastern Minnesota. Nova Hedwigia 31: 667-756.

Foged, N. 1982. Diatoms in Human tissue. Nova Hedwigia 36(2-4): 345-379.

Foged, N. 1986. Diatoms in Anholt, a Danish Island in the Cattegat. Nova Hedwigia 42(2-4): 553-589.

Gandhi, H.P. 1956-57. A contribution to our knowledge of the diatom genus Pinnularia. J. Bomb. Nat. Hist. Soc. 54: 845-852

Gandhi, H.P. 1960. Fresh water diatom flora of the Panhalgarh Hillfort in the Kolhapur district. Hydrobiol. 14(2): 93129

Habib, I. 1997. Algal flora from Mahendranagar, Nepal. $J$. Econ. and Taxon. Bot. (India) 21(1): 19-26.

Hendy, N.I. 1964. An introductory account of the smaller algae of British coastal water, Part V, Bacillariophyceae (Diatoms). H.M.S.O., London.

Hickel, B. 1973. Limnological investigations in lakes of Pokhara valley, Nepal. Int. Rev. ges Hydrobiol. 58(5): 659-672.

Hickel, B. 1973a. Phytoplanktons in two ponds in Kathmandu valley, Nepal. Int. Rev. ges Hydrobiol. 58(6): 835-842.

Hirano, M. 1955. Fresh water algae. In Fauna and flora of
Nepal Himalaya (Ed. H. Kihara). Fauna and Flora Research Society, Kyoto University, Japan. pp. 5-42.

Hirano, M. 1963. Fresh water algae from the Nepal Himalaya, collected by a member of the Japanese Climbing Expedition. Contr. Biol. Lab., Kyoto University, Japan. 16: $1-23$

Hirano, M. 1984. Fresh water algae from East Nepal. Study reported of Baika Junior College 32: 197-215.

Hustedt, F. 1938. Systematische und ökologische Unter suchungen über die Diatomeen flora von Java, Bali und Sumatra. Archiv f. Hydrobiol. Suppl. 15: 131-177, 187295, 293-506.

Hustedt, F. 1959. Die Kieselalgen Deutschlands, Österreichs Und der Schweiz, Vol. 2. Koeltz Scientific Books, USA $845 \mathrm{p}$.

Hustedt, F. 1961-66. Die Kieselalgen Deutschlands, Österreichs und der Schweiz unter Berücksichtigung der übrigen Länder Europas sowie der angrenzenden Meeresgebiete, Part 3, Vol. VII. B. Singh and M.P. Singh, Dehradun, India. $816 \mathrm{p}$

Ishida, Y. (Ed.) 1986. Studies on distribution, adaptation and evolution of microorganisms in Nepal Himalayas (2nd report). Kyoto, Japan. pp. 3-13.

Patrick, R. and C.W. Reimer 1966. The diatoms of the United States, exclusive of Alaska and Hawaii. Monograph of the Academy of Natural Sciences, Philadelphia, No. 13, Vol. I. 688 p.

Rothfritz, H., I. Juettner, A.M. Suren and S.J. Ormerod 1997. Epiphytic and epilithic diatom communities along environmental gradients in the Nepalese Himalaya: Implications for the assessement of biodiversity and water quality. Archiv $f$. Hydrobiol. 138(4): 465-482.

Shrestha, B. and J.D. Manandhar 1983. Contribution to the algal flora of Kathmandu valley. J. Inst. Sci. Techn. (Nepal) 6: 1-6.

Suxena, M.R. and V. Venkateswarlu 1968. Algae of the Cho Oyu (E. Himalaya) Expedition- I. Bacillariophyceae Hydrobiol. 32: 1-26.

Suxena, M.R., V. Venkateswarlu and V.S. Rao 1972. Algae of the Cho Oyu (E. Himalaya) ExpeditionII. Bacillariophyceae- II. Nova Hedwigia 23(2-3): 415-426.

Tiffany, L.H. and M.E. Britton 1952. The algae of Illinois. Hafner Publishing Co., New York. 407 p. 